\title{
Second Generation Ethanol - Technological Intensity on the Integrated Cycle
}

\author{
Pedro P. Senna', Stela L. M. Ansanelli ${ }^{2}$ \\ ${ }^{1}$ Doctoral Program in Engineering and Public Policies, Faculty of Engineering University of \\ Porto, Porto, Portugal (up201708818@fe.up.pt); ${ }^{2}$ Professor Ph.D. in Economics from the \\ Economics Department at State University of São Paulo (FCLAR/UNESP), Brazil \\ (stelaluiza@fclar.unesp.br)
}

\begin{abstract}
The purpose of this study is to investigate Second Generation Ethanol's (SGE) production cycle in order to understand the level of SGE's technological intensity in the integrated cycle. The suggested methodology comprises of a review of literature surrounding the requirements and indexes of technological intensity. A wide selection of database and review of specialized literature have been described to demonstrate the proposed discussion and conclusions. It has been observed that SGE puts forward a higher level of technological intensity in relation to First Generation Ethanol (FGE).
\end{abstract}

Author Keywords. Second Generation Ethanol, Technological Intensity

Type: Research Article

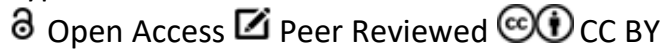

\section{Introduction}

From a literacy point of view, few researches have been conducted on the theme of First Generation Ethanol's (FGE) and Second Generation Ethanol's (SGE) integrated production cycle, specifically concerning SGE technological intensity when compared to FGE. In light of this fact, a reviewed analysis of specific literacy and empirical data has been conducted in order to discuss criteria for indexation and categorization of technological intensity regarding SGE.

On the early 2000's a great effort was given by world's leaders, led by the United States of America and Europe, to substitute their energy matrixes, at the time based upon fossil-fuels, for renewable energies. American leadership was given to ethanol's extraction domain regarding corn as feedstock, having great importance after international political affairs over oil production and commerce (Ansanelli et al. 2017).

This new impulse on the renewable energies reverberated positively on developing countries, especially Brazil, which used its ethanol extraction and production knowledge regarding sugarcane as feedstock as an alternative for gasoline with regards to its main vehicle fuel component. Government and private initiatives on automotive and sugar and alcohol sectors led to the creation of the flex-fuel bi-fuel engine, implemented with much success on national industry, being responsible for national ethanol's market development. Between 2003 and 2007 hydrated ethanol's demand rose $273.36 \%$, going from 3.792 thousand $\mathrm{m}^{3}$ in 2003 to 10.366 thousand $\mathrm{m}^{3}$ in 2007, which demonstrated the sector's expressive growth. Also, the implementation of flex-fuel vehicles on national market has risen to astonishing $90 \%$ of total national light-automotive production (EPE and MNE 2008).

FGE's Industrial process generates sugarcane bagasse and straws for residues, among other compounds, which are then used either on electric energy production or SGE's industrial 
production, on an integrated cycle (Dias 2011). Both FGE and SGE final products are the same in chemical composition, with differences regarding only the production characteristics, which provide an interesting advantage for the integrated cycle altogether (Ansanelli et al. 2017).

Although a wide variety of theoretical literacy can be found concerning specifically the topic of technological intensity, and the existence of a wide range of empirical data regarding SGE's implementation and possible outcomes, there is a lack on the economic literacy for the classification of SGE, when compared to FGE, aimed at the technological intensity point of view.

Therefore, this research is aimed towards establishing such a connection, in a briefly manner, of the description of criteria and indexes of technological intensity widely in use with the wide range of empirical data regarding SGE's economic and technological characteristics. For this purpose, the proposed article was written in sections which are divided in order to describe these areas separately and, afterwards, combining the empirical data and the theoretical point of view of technological intensity to establish the classification of SGE's technological intensity when compared to FGE, within the FGE/SGE integrated cycle.

\section{Materials and Methods}

An extensive bibliographic research has been conducted focusing on recently published materials (journals in national and international research publications, reports, websites and textbooks) regarding the theory of technological intensity and empirical data on Second Generation Ethanol when integrated into the First Generation Ethanol production cycle. The main principle applied for the bibliographic research was the PESTLE framework methodology, which focuses on: Political, Economic, Social, Technologic, Law and Environmental. This is an environmental analysis usually performed in order to reveal the factors on a macro-scale level (Kotler and Armstrong 2004). Originally developed for the SWOT analysis (strengths - weaknesses - opportunities - threats), in this case it was used in order to assure that the research conducted was aimed towards First Generation Ethanol's and Second Generation Ethanol's integrated cycle, whilst regarding its characteristics under these focuses. On this sense, relevant papers were found by searching online major scientific databases Science Direct, Web of Science, Google Scholar and Scopus, with the following keywords for identification of proposed relevant research:

- (first generation ethanol) OR (FGE) OR (etanol de primeira geração) OR (E1G) AND (second generation ethanol) OR (SGE) OR (etanol de segunda geração) OR (E2G) AND (integrated cycle) OR (ciclo integrado).

Overall, 235 reports, grey literature and papers were selected and analyzed. On this paper the most relevant of such research material was used, all aimed towards this research objectives which were to identify if SGE, on the integrated cycle, has a higher intensity level with respect to FGE's intensity level. From the original 235 research material, 20 are discussed in this paper having such objective in mind.

\section{Discussion over the theory of technological intensity and empirical Second Generation Ethanol's characteristics}

\subsection{Technological Intensity: a brief theoretical review}

Regarding technological intensity from firms and sectors, it is classified according to technological patterns used in production activities, allowing for a broader understanding of technological processes patterns, as well as improving problematic solutions for 
development. The possibility of process and analysis of a larger share of information, while improving the decision of decision maker's policies and innovation expertise researchers, demonstrates another advantage for the adoption of a standardized categorization. When firms are regarded, the technological classification applies for the presence of elevated levels of intrasector heterogeneity, underlying the argument for a standardized categorization specific to firms (Archibugi 2001; Cavalcante 2014).

Within the specialized literacy, many categorizations can be found, of which two are more often widespread used: i) The Organization for Economic Co-operation and Development's (OECD) classification, which brings together the transformation industry's sectors regarding their technological intensity; ii) Pavitt's (1984) proposed taxonomy, underlying its classification in regards to sectors patterns for technical changes.

Originally both of these categorizations propose four different categories: i) OECD's classification separates between sectors of high, medium-high, medium-low and low categories; while (ii) Pavitt's classification regards the groups between scale intensive, specialized suppliers (or technical progress diffusers), supplier dominated sector, and those sectors driven by science (Cavalcante 2014; Pavitt 1984).

On the other hand, related to sectors classification which are aimed towards arranging enterprises or production units according to common characteristics, those categorized through capital market processes and behaviors are distinguished. Sector categorizations based upon production process are often revised, so that the main international categorizations keep close correspondence to one-another, and are evident:

i) The International Standard Industrial Classification of all Economic Activities (ISIC) from United Nations' Statistical Division (UNSD);

ii) The North American Industry Classification Systems (NAICS), an American classification;

iii) The Statistical Classification of Economic Activities in the European Community (NACE), provided and used by the European Community;

iv) The National Classification of Economic Activities (CNAE), from Brazil.

In contrast, capital market's sectors classifications are aimed, in their majority, towards sector aggregation based upon enterprises with open capital, that is, firms and production units with stock markets. For this case, the main classifications are:

i) The Industry Classification Benchmark (ICB), financed and maintained by the Financial Times and Stock Exchange (FTSE), which can be associated to OECD's technological classification due to the usage of the same database;

ii) The Global Industry Classification Standard (GICS), maintained by Standard \& Poor's and Morgan Stanley Capital International (MSCl);

iii) And the Thomson Reuters Business Classification.

Regarding technological classifications, Hatzichronoglou (1997) has used the OECD's classification, with emphasis the use of methodology which considers both the specific technological level for each sector (measured through the relation between R\&D expenditures and added value), and the technological level present in sales of intermediate goods and capital. Therefore, OECD's technological classification may be seen as a quarterly aggregation based upon objective data collected from the firms. Hatzichronoglou's classification (Hatzichronoglou 1997) has suffered many revisions, the most recent from 2011, in which there are no explicit category for renewable energies or biofuels. In this sense, it was necessary to adequate such categories under "Other mineral products" (which 
are classified with medium-low technological intensity), or under "Chemicals except pharmaceutical" (which are classified with medium-high technological intensity) (Cavalcante 2014; Eurostat 2009; Hatzichronoglou 1997; OECD 2007; OECD 2011).

The difficulty in finding a sector categorization based upon production process is not observed in capital market's categorization, as it is found on the research of Ortega-Argilés, Potters, and Vivarelli (2011). This work has merged both NACE and ICB categorizations with the objective of obtaining a categorization regarding technological intensity, which is presented in three categories: high, medium and low technological intensity. Under this classification, the biotechnology's sector can be categorized with high technological intensity, with subdivisions between "chemical's manufacturing and production" (NACE code 24), and "Research and Development (R\&D)" (NACE code 73) (Cavalcante 2014; OrtegaArgilés, Potters, and Vivarelli 2011).

Although these classifications undertake the biotechnological sectors in mind, they lack measurement in regards to quantification of provided data. With this in mind, Ortega-Argilés et al. (2009) have proposed a calculation for technological intensity based upon R\&D intensity in relation to total revenues, having data collected from enterprises and firms on the United Kingdom (UK), in such a manner as to define technological intensity on ICB's sectors. As a result from this research, biotechnology is classified with high technological intensity, with intensity in relation to R\&D expenditures of $0.28 \%$ of total revenues (Cavalcante 2014; Ortega-Argilés et al. 2009).

In similar fashion, Moncada-Paternò-Castello et al. (2010) classified technological intensity of ICB's sectors under four distinct groups, having R\&D expenditures related to total revenues in mind:

i) High intensity R\&D (greater than $5 \%$ of total revenues);

ii) Medium-high intensity R\&D (between $2 \%$ and $5 \%$ of total revenues);

iii) Medium-low intensity R\&D (between $1 \%$ and $2 \%$ of total revenues);

iv) Low intensity R\&D (less than $1 \%$ ).

After the analysis of the different proposed classifications and methodologies it could be observed that OECD's technological categorization may be the more adequate when aggregation of economic sectors are aimed, due to its base assumptions being the R\&D expenditures related to added value and the technological level present in sales of intermediate goods and capital. Moreover, the methodology for indirect R\&D intensity is based upon measurement of the technological flow matrix of each country, annually given, taking into account the R\&D flow embedded in sales of intermediate goods and capital, either domestic or foreign. Therefore, R\&D total expenditure proposed in OECD's technological categorization considers direct and indirect R\&D expenditures, which provides more accountability and credibility for the obtained results (Hatzichronoglou 1997).

A brief summary of the main criteria and categories for technological intensity can be found on Table 1. 


\begin{tabular}{|c|c|c|}
\hline Author(s) & Technological intensity criteria & Technological intensity categories \\
\hline $\begin{array}{l}\text { OECD (2007, } \\
\text { 2011) }\end{array}$ & $\begin{array}{l}\text { Considers the specific level for each } \\
\text { sector, measured through R\&D } \\
\text { expenditures and added value. Also } \\
\text { takes into account the technological } \\
\text { level present in sales of intermediate } \\
\text { goods and capital. }\end{array}$ & $\begin{array}{l}\text { High intensity } \\
\text { Medium-high intensity } \\
\text { Medium-low intensity } \\
\text { Low intensity }\end{array}$ \\
\hline $\begin{array}{l}\text { Ortega-Argilés, } \\
\text { Potters, and } \\
\text { Vivarelli (2011) }\end{array}$ & $\begin{array}{l}\text { Based upon aggregation of NACE and } \\
\text { ICB categorizations. }\end{array}$ & $\begin{array}{l}\text { High intensity } \\
\text { Medium intensity } \\
\text { Low intensity }\end{array}$ \\
\hline $\begin{array}{c}\text { Moncada- } \\
\text { Paternò-Castello } \\
\text { et al. (2010) }\end{array}$ & $\begin{array}{l}\text { Regards the relationship between } R \& D \\
\text { expenditures and total revenues. }\end{array}$ & $\begin{array}{l}\text { High intensity R\&D } \\
\text { Medium-high intensity R\&D } \\
\text { Medium-low intensity R\&D } \\
\text { Low intensity R\&D }\end{array}$ \\
\hline Pavitt (1984) & $\begin{array}{l}\text { Classifies according to sectors' standards } \\
\text { regarding technical changes. }\end{array}$ & $\begin{array}{c}\text { Scale intensive } \\
\text { Specialized suppliers (or technical } \\
\text { progress diffusers) } \\
\text { Supplier dominated sectors } \\
\text { Science driven sectors }\end{array}$ \\
\hline
\end{tabular}

Table 1: Summary of different criteria and categories for technological intensity

\subsection{Second Generation Ethanol's empirical characteristics}

Second Generation Ethanol (SGE), is produced through manipulation of First Generation Ethanol's (FGE) residues, which can be originated either from sugarcane biomass, wheat biomass or wheat biomass. In this research we will approach SGE produced from sugarcane biomass residues, namely, sugarcane bagasse and straws in the form of lignocellulosic material (LCM). SGE is obtained through the Second Generation Industrial Stage, starting with the bagasse and straw's pretreatment, which can be done either through diluted acid, steam explosion, or alkaline hydrogenation. Afterwards the pre-treated bagasse goes through hydrolyses treatment, which can be either acidic or enzymatic, resulting in the preparation of the SGE'S must, thereafter being conducted to the fermentation stage alongside FGE's prepared must. The FGE/SGE integrated cycle can be observed on Figure 1 below, regarding the main stages of production for each generation. On average, $280 \mathrm{~kg}$ of bagasse with $50 \%$ humidity are generated from each ton of processed sugarcane, from which fibers are the main substratum for SGE's production. Since both generations of ethanol produce the same final product, which is hydrated ethanol or anhydrous ethanol, both enjoy from the same advantages of a rising market and demand, especially in Brazil, where there are flex-fuels vehicles being produced since the early 2000's, and which may be fueled either by gasoline or hydrated ethanol (Costa 2014; Stucchi 2016). 


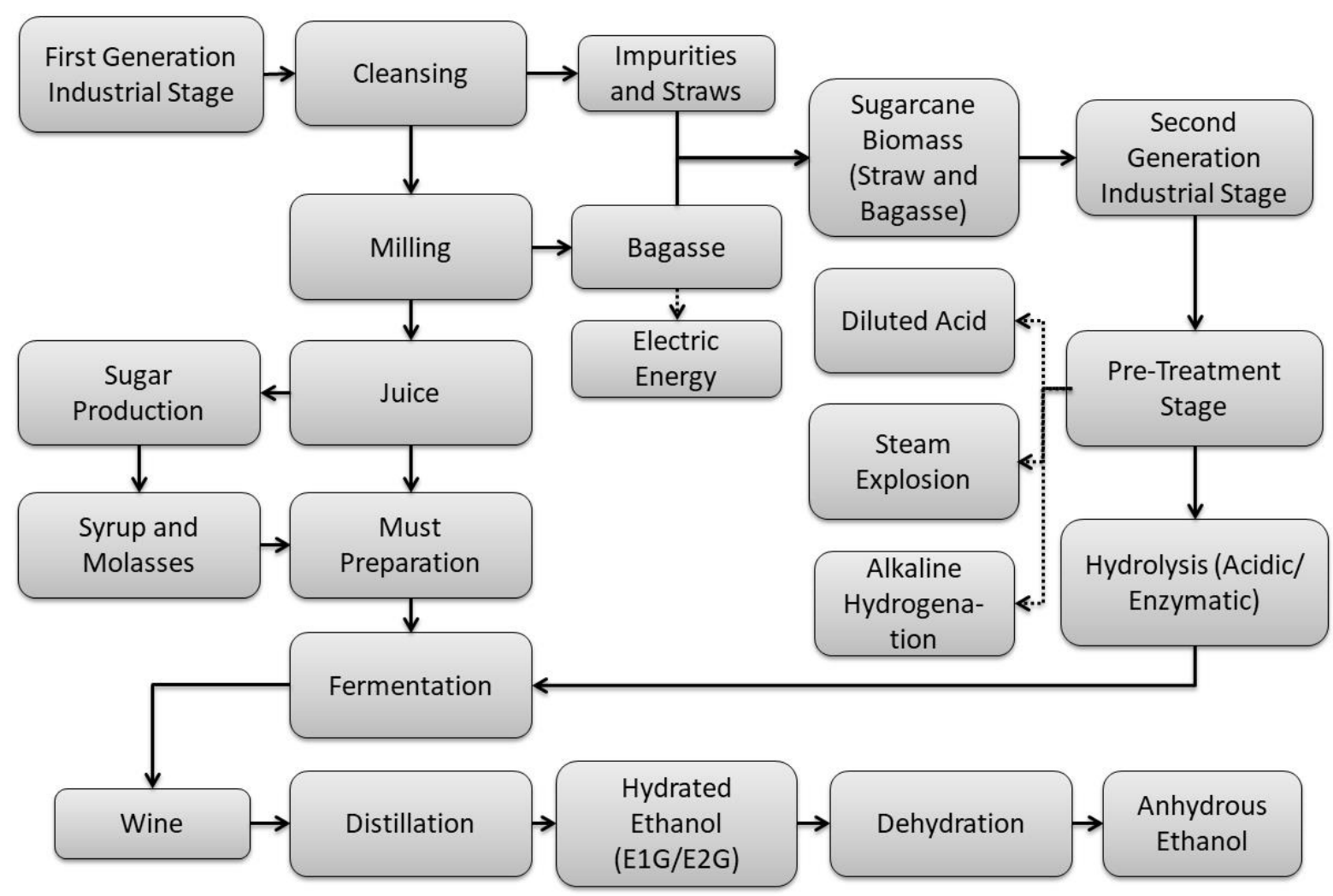

Figure 1: FGE/SGE integrated cycle

Regarding minimum sale prices, which bear critical importance for this research since it aggregates R\&D expenditures, among other variables, it was observed that sugarcane SGE's minimum sale price was higher than sugarcane FGE's minimum sale price, according to Raízen company's data (US\$0.57 per liter for SGE's minimum sale price compared to FGE's US\$0.22 per liter minimum sale). In another comparison, Raízen Company's data has shown that production costs for FGE and SGE are at similar levels, when regarding sugarcane as feedstock for both processes, being registered at US\$ 0.22 per liter for FGE against US\$ 0.26 per liter for SGE. The choice for pre-treatment is of utmost importance as well as the feedstock from which FGE and SGE will be produced. A comparison of different feedstocks, production capacity and pre-treatment choices is demonstrated in Table 2, for all firms with SGE's commercial scale production (Costa 2014; Stucchi 2016).

\begin{tabular}{c|c|c|c}
\multirow{2}{*}{ COMPANY } & \multirow{2}{*}{ Feedstock } & Production Cap. $\left.\mathbf{~}^{*}\right)$ & Pre-treatment \\
\cline { 3 - 4 } & & $\left(10^{6}\right.$ liters per year $)$ & Choice \\
\hline Raízen & Sugarcane bagasse & 40.1 & Diluted acid \\
\hline GranBio & Sugarcane straw & 83.2 & Steam explosion \\
\hline Poet-DMS & Corn straw & 94.6 & Diluted acid \\
\hline Beta Renewables & Wheat straw & 75.7 & Alkaline hydrogenation \\
\hline DuPont & Corn Straw & 113.5 & Diluted acid \\
\hline Abengoa & Corn Straw & 94.6 & \\
\hline
\end{tabular}

Table 2: Basic characteristics of SGE's commercial scale plants

Currently there are many different methods for SGE's production that take into account substratum characteristics and the system already employed for FGE's production, especially when considering the use of enzymatic hydrolysis. In regards to enzyme characteristics, the 
most prominent are final product volume, enzyme denaturation and irreversible enzyme adsorption on the substratum. On the other hand, the main factors in regards to the substratum are the lignin, porosity, cellulose fibers crystallinity and hemicellulose content, among others (Moreira et al. 2015; Piccolo and Bezzo 2009).

The conversion rate of cellulosic residues into glycose, which is necessary for ethanol's production, was estimated around $90.85 \%$ while the alcoholic fermentation processes yield was estimated in $85.35 \%$, at temperatures of $120^{\circ} \mathrm{C}$, on pre-treatment stage. Presently, researches on the field are aiming for the integration of hydrolysis and fermentation stages into a single stage, namely, the Simultaneous Saccharification and Fermentation (SSF) stage. This single stage main advantage is to conceive larger amount of ethanol production with lesser use of enzyme's volume (Albarelli 2013; Piccolo and Bezzo 2009).

Economic analysis results - FGE/SGE integration on single integrated cycle

\begin{tabular}{|c|c|c|c|}
\hline \multicolumn{4}{|c|}{ Facilities Investments } \\
\hline Sector & SGE & Integrated FGE/SGE & Var. \\
\hline First Generation (FGE) & US\$ 193,5 mi & US\$ 194,3 mi & $0,41 \%$ \\
\hline Second Generation (SGE) & US\$ $106,7 \mathrm{mi}$ & US\$ 52,6 mi & $-50,70 \%$ \\
\hline Common Stages (FGE/SGE) & US\$ 33,3 mi & US\$ 42,2 mi & $26,73 \%$ \\
\hline Total & US\$ $333,5 \mathrm{mi}$ & US\$ 289,1 mi & $-13,31 \%$ \\
\hline \multicolumn{4}{|c|}{ Economic analysis estimates } \\
\hline Investment Costs (CIF) & \multirow{2}{*}{ US\$ $333,5 \mathrm{mi}$} & \multirow{2}{*}{ US\$ 289,1 mi } & \multirow{2}{*}{$-13,31 \%$} \\
\hline (US\$) & & & \\
\hline Working Capital (WC) & \multirow{2}{*}{ US\$ 16,7 mi } & \multirow{2}{*}{ US\$ $14,9 \mathrm{mi}$} & \multirow{2}{*}{$-10,77 \%$} \\
\hline (US\$) & & & \\
\hline Annualized Inv. Costs (AC) & \multirow{2}{*}{ US\$ 66,4 mi } & \multirow{2}{*}{ US\$ 59,3 mi } & \multirow{2}{*}{$-10,69 \%$} \\
\hline (US\$) & & & \\
\hline Income (I) & \multirow{2}{*}{ US\$ 165,1 mi } & \multirow{2}{*}{ US\$ 233,6 mi } & \multirow{2}{*}{$41,49 \%$} \\
\hline (US\$) & & & \\
\hline Operational Costs (OP) & \multirow{2}{*}{ US\$ 117,2 mi } & \multirow{2}{*}{ US\$ $114,5 \mathrm{mi}$} & \multirow{2}{*}{$-2,30 \%$} \\
\hline (US\$) & & & \\
\hline Economic Potential (EP) & \multirow{2}{*}{ US\$ 47,9 mi } & \multirow{2}{*}{ US\$ $119 \mathrm{mi}$} & \multirow{2}{*}{$148,43 \%$} \\
\hline (US\$) & & & \\
\hline Net Present Value (NPV) & \multirow{2}{*}{ US\$ 20,5 mi } & \multirow{2}{*}{ US\$ $308 \mathrm{mi}$} & \multirow{2}{*}{$1402,43 \%$} \\
\hline (US\$) & & & \\
\hline Income Return Rate (IRR) & \multirow{2}{*}{$10,80 \%$} & \multirow{2}{*}{$21,40 \%$} & \multirow{2}{*}{ 10,6 p.p. } \\
\hline (\%) & & & \\
\hline Payback Time (PB) & \multirow{2}{*}{7,3 years } & \multirow{2}{*}{2,6 years } & \multirow{2}{*}{$-64,38 \%$} \\
\hline (years) & & & \\
\hline
\end{tabular}

Table 3: Investment on integrated plants

In regards to the FGE/SGE integrated cycle on active plants, the introduction of SGE technological paradigm would contribute for a productivity increase of $31 \%$ to $75 \%$ compared to current levels (which take into account FGE's production on a stand-alone position). The same integration could generate reduction of $50.70 \%$ on SGE's production 
costs and approximately $90 \%$ on the overall costs of the integrated cycle (Albarelli 2013; Andrade 2012; CGEE 2008; Costa 2014; Milanez et al. 2015).

From an economic point of view, the integrated cycle could generate a $10.69 \%$ reduction of annualized investment costs and working capital, while causing the return of investment time to be reduced up to $64.38 \%$. On the other hand, the integration of FGE and SGE production cycles into a single integrated cycle would increase the income on, approximately 41.49\%; the economic potential on $148.43 \%$; and net present value on $1402.43 \%$, all of which are shown on Table 3 (Albarelli 2013).

On the long term, with regards to reviewed projections, it would be possible to have SGE's production volume of 350 million liters per year with annual investment of US\$ 80 million, which would render the possibility of production costs reduction, going from US\$ 1.50 per liter on the short term to US\$ 0.50 per liter on the long term (Albarelli 2013; Ansanelli et al. 2017; Dias 2011; Milanez et al. 2015).

\section{Conclusions}

Technological intensity, as classified regarding technological patterns of production activities, allows for a wide comprehension of standards in technological progress while providing solutions for development problematics. From the technological intensity categorizations discussed, this research focus on those proposed by OECD and Pavitt's taxonomy. From OECD's classification, SGE can be categorized as having high technological intensity, while being classified as progress diffusor under Pavitt's taxonomy.

These conclusions can be drawn from the fact that SGE requires high R\&D investments in relation to total revenues while putting forward high levels of embedded technology on intermediate goods and capital sales, as well as resources, bio-refinery equipment and enzymes. In spite of all efforts, it has not yet reached commercial scale productivity from a cost-effectiveness stability point of view. As such, it could not be considered, under Pavitt's taxonomy, as scale intensive, although it has provided enough characteristics to be classified, under OECD's categorization, as high technological intensity.

In spite of such categorizations, it is important to note that the literacy regarding FGE/SGE integrated cycle is still incipient, presenting many challenges on indexation and categorization of technological intensity, especially when regarding developing countries, such as Brazil's case. Therefore, more research is required on the field, specific empirical research from both cost-effectiveness and R\&D investment points of view, in order to allow for the adoption of standardized categorizations of such incipient technology. New researches regarding objective measurement of embedded technologies both in supplies and needed goods along the production process of the integrated cycle are required as well, in order to establish more credible grounds for the conclusions hereby drawn.

\section{References}

Albarelli, Juliana Queiroz. 2013. "Produção de açúcar e etanol de primeira e segunda geração: simulação, integração energética e análise econômica". PhD diss., Faculty of Chemical Engineering, Unicamp. http://repositorio.unicamp.br/jspui/handle/REPOSIP/266572.

Andrade, Rafael Ramos de. 2012. "Modelagem cinética do processo de produção de etanol a partir de hidrolisado enzimático de bagaço de cana-de-açúcar concentrado com melaço considerando reciclo de células". PhD diss., Faculty of Chemical Engineering, Unicamp. http://repositorio.unicamp.br/jspui/handle/REPOSIP/266773. 
Ansanelli, Stela, Pedro Pinho Senna, Daniel Augusto Coração de Campos, and Guilherme Ribeiro da Silva. 2017. "Sistemas de inovação ambiental em países em desenvolvimento: Uma discussão a partir do desenvolvimento do etanol de segunda geração no Brasil". Pesquisa \& Debate. Revista do Programa de Estudos Pós-Graduados em Economia Política 28 (1(51)): 121-39. https://revistas.pucsp.br/index.php/rpe/article/view/32895.

Archibugi, Daniele. 2001. "Pavitt'S taxonomy sixteen years on: A review article". Economics of Innovation and New Technology 10 (5): 415-25. DOI: 10.1080/10438590100000016.

Cavalcante, Luiz Ricardo. 2014. Classificações tecnológicas: Uma sistematização. Brasília: IPEA - Instituto de Pesquisa Econômica Aplicada. Accessed November 26, 2017. http://www.ipea.gov.br/portal/index.php?option=com_content\&view=article\&id=21829.

CGEE - Centro de Gestão e Estudos Estratégicos. 2008. Bioetanol de cana-de-açúcar: energia para o desenvolvimento sustentável. Rio de Janeiro: Banco Nacional de Desenvolvimento Econômico e Social (BNDES).

Costa, Aline Carvalho da. 2014. "Caso de sucesso: produção de etanol (2 2 a Geração)". Laboratório de Engenharia de Processos Fermentativos e Enzimáticos (LEPFE) - Faculty of Chemical Engineering, Unicamp. https://www.crq4.org.br/sms/files/file/caso_sucesso_aline_costa_etanol2.pdf.

Dias, Marina Oliveira de Souza. 2011. "Desenvolvimento e otimização de processos de produção de etanol de primeira e segunda geração e eletricidade a partir da cana-deaçúcar". PhD diss., Faculty of Chemical Engineering, Unicamp. http://repositorio.unicamp.br/jspui/handle/REPOSIP/266828.

EPE - Empresa de Pesquisa Energética, and MNE - Ministério de Minas e Energia. 2008. Cadernos de Energia EPE - Perspectivas para o etanol no Brasil.

Eurostat. 2009. "High-technology and knowledge based services aggregations based on NACE Rev. 2". Accessed November 26, 2018. http://ec.europa.eu/eurostat/cache/metadata/Annexes/htec_esms_an3.pdf.

Hatzichronoglou, T. 1997. Revision of the High-Technology Sector and Product Classification. OECD Science, Technology and Industry Working Papers, No. 1997/2, OECD, Paris.

Kotler, Philip and Gary Armstrong. 2004. Principles of marketing. Upper Saddle River: Prentice-Hall.

Milanez, Artur Yabe, Diego Nyko, Marcelo Soares Valente, Luciano Cunha Sousa, Antonio Maria Francisco Luiz Jose Bonomi, Charles Dayan Farias de Jesus, Marcos Djun Barbosa Watanabe, Mateus Ferreira Chagas, Mylene Cristina Alves Ferreira Rezende, and Otávio Cavalett. 2015. "De promessa a realidade: como o etanol celulósico pode revolucionar a indústria da cana-de-açúcar: uma avaliação do potencial competitivo e sugestões de política pública". $\quad$ BNDES Setorial (41): 237-94. https://web.bndes.gov.br/bib/jspui/handle/1408/4283.

Moncada-Paternò-Castello, Pietro, Constantin Ciupagea, Keith Smith, Alexander Tübke, and Mike Tubbs. 2010. "Does Europe perform too little corporate R\&D? A comparison of EU and non-EU corporate R\&D performance". Research Policy 39 (4): 523-36. DOI: 10.1016/j.respol.2010.02.012.

Moreira, R. F., O. Almeida, N. T. Machado, E. M. S. Rodrigues, A. M. J. C. Neto, M. A. Cordeiro, B. R. Chagas, E. L. G. Tenoro, M. L. F. Teixeira, and P. R. Veiga da Silva. 2015. "Produção de Bioetanol a partir da hidrólise enzimática do bagaço de cana-de-açúcar". XX Congresso Brasileiro de Engenharia Química 1 (2). DOI: 10.5151/chemeng-cobeq20140261-26291-181973. 
OECD. 2007. "Annex 1: Classification of manufacturing industries based on technology". In OECD Science, Technology and Industry Scoreboard 2007, 219-21. DOI: 10.1787/sti_scoreboard-2007-en.

OECD. 2011. "ISIC Rev. 3 Technology intensity definition". OECD Directorate for Science, Technology and Industry. https://www.oecd.org/sti/ind/48350231.pdf.

Ortega-Argilés, Raquel, Mariacristina Piva, Lesley Potters and Marco Vivarelli. 2010. "Is corporate R\&D investment in high-tech sectors more effective? Some guidelines for European Research Policy". Contemporary Economic Policy 28 (3): 353-65. https://www.iza.org/publications/dp/3945.

Ortega-Argilés, Raquel, Lesley Potters, and Marco Vivarelli. 2011. "R\&D and productivity: Testing sectoral peculiarities using micro data". Empirical Economics 41 (3): 817-39. DOI: 10.1007/s00181-010-0406-3.

Pavitt, Keith. 1984. "Sectoral patterns of technical change: Towards a taxonomy and a theory". Research Policy 13 (6): 343-73. DOI: 10.1016/0048-7333(84)90018-0.

Piccolo, Chiara, and Fabrizio Bezzo. 2009. "A techno-economic comparison between two technologies for bioethanol production from lignocellulose". Biomass and Bioenergy 33 (3): 478-91. DOI: 10.1016/j.biombioe.2008.08.008.

Stucchi, António Alberto. 2016. "A experiência da Raízen com E2G e perspectivas para o futuro". Presented in NovaCana Ethanol Conference 2016. Accessed November 26, 2018. https://www.novacana.com/n/eventos/a-experiencia-da-raizen-com-o-etanol-desegunda-geracao-130616/. 